\title{
GROWTH OF ORNAMENTAL GRASSES UNDER SALINITY STRESS
}

\author{
Monika HENSCHKE* \\ Poznań University of Life Sciences \\ ul. Dąbrowskiego 159, 60-594 Poznań Poland
}

Received: September 2016; Accepted: December 2016

\begin{abstract}
The aim of this study was to determine the effect of substrate salinity caused by increasing $\mathrm{NaCl}$ doses on growth and development of ornamental grasses: Briza media L., Deschampsia cespitosa (L.) P. Beauv., Koeleria glauca (Spreng.) DC., Sesleria caerulea (L.) Ard. and Sorghastrum nutans (L.) Nash. Results provide the basis for the preliminary classification of analyzed grasses in terms of their tolerance to substrate salinity. Grasses, responding negatively to substrate salinity caused by small doses of 5 and $10 \mathrm{~g} \cdot \mathrm{NaCl} \cdot \mathrm{dm}^{-3}$, may be considered to be sensitive species. Within the studied genotypes, B. media showed a negative response to salt stress in most of the analyzed traits. Genotypes responded differently to salinity but all had a decreased tolerance index even at the lowest concentration of $\mathrm{NaCl}$. The lowest percentages of dry leaves at 5 and $10 \mathrm{~g} \mathrm{NaCl} \cdot \mathrm{dm}^{-3}$ were in $K$. glauca and $S$. caerulea. The percentage of dry matter and leaf greenness were least affected.
\end{abstract}

Key words: shoots, dry matter content, leaf chlorophyll content index, leaves, sodium chloride

\section{INTRODUCTION}

Saline soils are found on every continent and are particularly common in desert and arid regions (Siyal et al. 2002). Frequently, human activity, such as mineral fertilization and industry, contributes to soil salinity. The impact of sodium chloride used in road de-icing is considered to be less important. This source of soil salinization is often underestimated, since it does not directly affect plant production. However, in view of the amount of $\mathrm{NaCl}$ applied in road de-icing, this problem is gaining in importance not only in Europe, but also in North America and Canada (Howard \& Maier 2007; Cunningham et al. 2008).

Under salinity stress, plants need to adapt their metabolism to environmental changes. Survival under these stress conditions depends on the capability of plants to detect a stimulus, generate and transmit signals, as well as induce biochemical changes, which will accordingly modulate metabolism (Rani 2011). If the salt content in soil exceeds the threshold level, first of all the water uptake capacity of plants is reduced, leading to osmotic stress (Xiong $\&$ Zhu 2002). Salt contained in the soil leads directly to ion stress (Munns 2002). Ions of $\mathrm{Na}^{+}$and $\mathrm{Cl}^{-}$may be accumulated in leaves and cause several types of damage in plants. The basic symptoms of salt stress include growth retardation and reduction of dry matter. Ion balance is disturbed and photosynthetic pigments are degraded. As a result of stress, the catabolic processes may dominate over anabolic processes and cause accelerated ageing, shedding of leaves and withering of plants. Many species are capable of avoiding the stressor by generating barriers countering penetration of harmful ions inside the plants, regulating ion transport and capacity to accumulate them (Warren et al. 1985; Warren \& Brockelman 1989; Cheong \& Yun 2007). Halophytes were found to be equipped with the largest number of mechanisms of resistance to salinity. In turn, glycophytes have a limited capacity to avoid harmful ions, which are eventually accumulated in leaf cells in toxic amounts (Farooq \& Azam 2006). However, sensitivity to salinity and resistance reactions vary greatly, to a considerable 
degree depending on the species or even a cultivar (Sudhakar et al. 2001).

Ornamental grasses are an interesting group of plants, recently gaining in importance. Many species exhibit a tolerance to adverse growth conditions (Dana 2002; Henschke 2014); thus, among them, we need to search for species resistant to salinity and in this way, broaden the currently limited assortment of plants for roadside green areas. The aim of this study was to determine the effects of substrate salinity caused by increasing the doses of $\mathrm{NaCl}$ on growth and development of ornamental grasses: Briza media L., Deschampsia cespitosa (L.) P. Beauv., Koeleria glauca (Spreng.) DC., Sesleria caerulea (L.) Ard. and Sorghastrum nutans (L.) Nash.

\section{MATERIAL AND METHODS}

\section{Plant material}

An experiment was conducted at the Marcelin Experimental Station in a greenhouse of the Poznan University of Life Sciences in the years of 2010, 2011 and 2012. Breeding clones of five species of perennial grasses were studied. Briza media L. comes from Eurasia, grows on meadows, frameworks and moors. Clumps of leaves grow to 15$25 \mathrm{~cm}$ of height; during the flowering, the height is $90 \mathrm{~cm}$. B. media, as an ornamental plant, can be cultivated in gardens and parks. Deschampsia cespitosa (L.) P. Beauv., which comes from Eurasia and America, grows on wet meadows, moors, alluviums, in forests and brushwoods. Clump of leaves grows to $30-50 \mathrm{~cm}$ of height, during flowering the height is $150 \mathrm{~cm}$. D. cespitosa can be cultivated in gardens and parks. Koeleria glauca (Spreng.) DC. comes from Europe and north Asia, grows on sandy dunes and alluviums in pine forests. Clumps of leaves grow to $20 \mathrm{~cm}$ of height, length of inflorescence stem is $60 \mathrm{~cm}$. K. glauca can be planted in gardens and urban greenery. Sesleria caerulea (L.) Ard. comes from Eurasia, grows on wet meadows and low peat bogs. The height of plants is $20-50 \mathrm{~cm}$. $S$. caerulea can grow in gardens and urban greenery. Sorghastrum nutans (L.) Nash. comes from North America, grows on prairies, in brushwoods and at roadside. The height of the clump of leaves is $50 \mathrm{~cm}$ and $150 \mathrm{~cm}$ during the flowering. It can be planted in gardens and parks (Foerster 1978).

The cuttings of grasses were obtained from division of rhizomes. They were grown from 4 May until 21 June in boxes under low tunnels made of white nonwoven ground cover. At that time, young plants were transplanted to pots of $0.750 \mathrm{dm}^{3}$. They were grown for 6 weeks in the substrate of Highmoor peat (Klasmann, pH 3,9) with washed mineral sand at a $20: 1$ ratio (v:v). The Highmoor peat was limed on the basis of neutralization curve to $\mathrm{pH} 6.40 \mathrm{using}$ $\mathrm{CaCO}_{3}$ at a dose of $7.0 \mathrm{~g} \cdot \mathrm{dm}^{-3}$ peat. The ready-touse substrate mixtures were supplemented with $2 \mathrm{~g} \cdot \mathrm{dm}^{-3}$ of a Peters Professional PL Special fertilizer $(20: 20: 20)$. Each pot contained the same weight of the substrate. At that stage, $B$. media developed 11 shoots and 18 leaves, and the length of the flag leaf was $29.2 \mathrm{~cm}, D$. cespitosa developed 7 shoots and 7 leaves, and the average length of the flag leaf was $29.7 \mathrm{~cm}$. K. glauca developed 4 shoots and 12 leaves, and the average length of the flag leaf was $13.4 \mathrm{~cm}$. S. caerulea developed 2-3 shoots and 5-6 leaves, and the length of the average flag leaf was $28.0 \mathrm{~cm}$, while $S$. nutans developed 4 shoots and 4 leaves and the average length of its flag leaf was $37.6 \mathrm{~cm}$.

\section{Treatments}

In the beginning of August, the plants were treated with salt solutions. One day before, an analysis of the substrate was made, which showed that it contained $\left(\mathrm{mg} \cdot \mathrm{dm}^{-3}\right): \mathrm{N}-\mathrm{NO}_{3} 83.3, \mathrm{P} 25.4, \mathrm{~K} 75.0$, $\mathrm{Ca} 250.7, \mathrm{Mg} 22.7, \mathrm{Cl} 12.5, \mathrm{pH}$ in $\mathrm{H}_{2} \mathrm{O}$ 6.1, $\mathrm{EC} \mathrm{mS} \cdot \mathrm{cm}^{-1} 2.0$. The plants were subjected to salt stress induced by a range of $\mathrm{NaCl}$ concentration $\left(\mathrm{g} \cdot \mathrm{dm}^{-3}\right): 0$ (control), 5, 10, 15, 30 and the electrical conductivity (EC) of soil saturation extract was $\left(\mathrm{mS} \cdot \mathrm{cm}^{-1}\right): 2.0,2.5,3.5,4.0,5.7$. In each variant, $100 \mathrm{ml}$ of saline solution was poured into the pot and $100 \mathrm{ml}$ of distilled water was used in the control. Each pot was placed on a bowl to prevent an uncontrolled outflow of saline. Prior to treatment of plants with salt solutions, the substrates were watered to 50-55\% moisture by weight of the substrate. Treatment with salt solutions was done only once. While growing, the plants were watered to $55-60 \%$ moisture by weight of the substrate. The experiment 
was conducted under natural photoperiod at quantum irradiance of $300-400 \mu \mathrm{mol} \cdot \mathrm{m}^{-2} \cdot \mathrm{s}^{-1}$, the average temperature and air humidity depended on the year of cultivation and it was respectively: 22 $24{ }^{\circ} \mathrm{C}, 45-50 \%$ in August and $17-19^{\circ} \mathrm{C}, 45-50 \%$ in September.

\section{Measurements}

The measurements, which were performed after 8 weeks of cultivation under saline conditions included the growth parameters, the percentage of dry leaves relative to the total number of leaves, the percentage of dry matter, leaf chlorophyll content (SPAD) and tolerance indices. Growth parameters included: the number of mature shoots (with at least one mature leaf - deflected into right angle from shoot) and of juvenile shoots, the length of shoots (cm) (measured from substrate surface to flag leaf) - a mean of three randomly selected mature shoots per plant and the length of leaves $(\mathrm{cm})$ - a mean of three fully developed leave blades on randomly selected shoots per plant.

The leaf chlorophyll content (SPAD) measured in proximal and adaxial part of young leaf, using a SPAD-502 Chlorophyll Meter was determined according to Gregorczyk and Raczyńska (1997) and Gregorczyk et al. (1998). It was not measured in $K$. glauca as the leaves were too narrow.

Tolerance index related to salinity (\%) was determined by Shetty et al. (1995) according to the formula $\mathrm{Ti}=$ dry mass at salinity level $\times 100 /$ dry mass at the 0.0 level of salinity.

\section{Experimental design}

The experiment was conducted as a random process. The treatments with different salt doses (0control, 5, 10, 15, $30 \mathrm{~g} \mathrm{NaCl} \cdot \mathrm{dm}^{-3}$ ) was a factor of study. Grass species were analyzed separately. The experiment was repeated for three years (2010, $2011,2012)$. One year was treated as replication in time. Each treatment consisted of three replications (years) with twelve plants for each one species. Each plant was cultivated in a separate pot.

\section{Statistical analysis}

The obtained results were analyzed statistically by means of analysis of one-way variance. The Newman-Keuls test at the significance level of $p=0.05$, was employed to analyze differences between the measured parameters.

\section{RESULTS AND DISCUSSION}

Growth under salt stress inhibited the growth of all studied genotypes including the number of shoots, length of shoots and leaves, and the degree of adverse effects increased with the concentration of $\mathrm{NaCl}$ in water solution. The exemptions were $S$. nutans (number of shoots and length of leaves not decreased) and $S$. caerulea (the same length of shoots) (Table 1). The lowest level of salinity had the negative effect on three growth parameters of B. media, whereas in $D$. cespitosa only the number of mature shoots was lower. In $K$. glauca and in S. caerulea the number of mature shoots and the length of leaves were lower. The highest salt concentration in watering solution reduced the number of mature and young shoots of $D$. cespitosa almost 3 times, although the length of shoots and leaves decreased at the highest concentration of $\mathrm{NaCl}$ only 1.5 times. In the other species, the number of shoots decreased from 1.4 to 2.2 times. Salt at 5 and $10 \mathrm{~g} \mathrm{NaCl} \cdot \mathrm{dm}^{-3}$ did not influence the length of shoots of the four species, and reduced the length of shoots significantly in $S$. nutans only. The greatest tolerance to the lowest dose of salt expressed in growth inhibition was found in S. nutans. In this species, the number of shoots and length of leaves were not changed.

Growth is the final effect of morphological expression of various metabolic activities taking place in plants. The negative effect of salinity inhibiting cell elongation may be manifested in the reduction of the number and length of shoots and leaves (Katerij et al. 1998). According to Glenn (1987), even grasses accounted to halophytes grow faster on nonsaline substrate. The response is found in leaves and mature shoots first, while young shoots, as sites of cell differentiation, are exposed to the effects of salinity to a lesser extent. In this study, only $S$. nutans did not decrease the number of juvenile shoots and the length of leaves (Table 1). Among the examined species, $S$. nutans had the least number of shoots. Moreover, they were the longest. Thus, it may be stated that $S$. nutans showed certain adaptations to growth under salinity. Tolerance of lower salt concentrations may result solely from the inhibitory action of osmotic stress. In the case of halophytes, the salinity causes mainly osmotic stress, while glycophytes are also exposed to ion stress (Xiong \& Zhu 
2002). The effect of salinity on the number of grass shoots was also investigated by Vasquez et al. (2006). They showed that under the influence of increasing salt doses, the plants produced less shoots. Phragmites australis, a species exhibiting greater sensitivity, at the largest dose produced almost $90 \%$ fewer shoots than in the control without salinity, whereas in the resistant species Spartina alterniflora, the number of shoots was only $40 \%$ lower. The negative effect of salinity on shoots growth in Spartina patens, was reported by Wu et al. (1998), while such a negative effect on plant height in Phragmites australis and Spartina alterniflora by Vasquez et al. (2006).

In this experiment, a particularly large percentage of dry leaves under the influence of salinity was observed in B. media (Table 2). The rate of dry leaves increased with increasing salt concentration and at the $30 \mathrm{~g} \mathrm{NaCl} \cdot \mathrm{dm}^{-3}$, it was 10.2 times greater than in control plants. Considering that it is a plant of abundant growth with a large number of shoots and leaves, both dehydration and accumulation of harmful ions in that species caused withering of a large number of leaves. Many dry leaves were also formed by $K$. glauca and S. caerulea. The highest dose of salt $\left(30 \mathrm{~g} \mathrm{NaCl} \cdot \mathrm{dm}^{-3}\right)$ caused a significant increase in the number of dry leaves 4.8 and 5.5 times, respectively comparing with control. Withering of mature leaves is a primary symptom of salt stress. It is a consequence of dehydration and accumulation of $\mathrm{Na}^{+}$and $\mathrm{Cl}^{-}$ions. Accumulation of those ions in leaves of grasses was reported by Glenn (1987). The effect of salinity on plant growth may be greatly varied depending on the species and its genotype, and produced phytohormones (Javid et al. 2001).

Table 1. The effect of salinity stress on growth parameters of ornamental grasses

\begin{tabular}{|c|c|c|c|c|c|}
\hline \multirow{2}{*}{ Species } & \multicolumn{5}{|c|}{ Salt concentration $\left(\mathrm{g} \mathrm{NaCl} \cdot \mathrm{dm}^{-3}\right)$ (proportion to control in brackets) } \\
\hline & 0 & 5 & 10 & 15 & 30 \\
\hline \multicolumn{6}{|l|}{ Number of mature shoots } \\
\hline Briza media & $18.4 \mathrm{e}^{*}$ & $15.6 \mathrm{~d}$ & $13.1 \mathrm{c}$ & $9.7 \mathrm{~b}$ & $7.1 \mathrm{a}(2.6)$ \\
\hline Deschampsia cespitosa & $23.8 \mathrm{e}$ & $18.7 \mathrm{~d}$ & $16.0 \mathrm{c}$ & $12.5 \mathrm{~b}$ & 8.8 a $(2.7)$ \\
\hline Koeleria glauca & $26.9 \mathrm{~d}$ & $21,5 \mathrm{c}$ & $18.5 \mathrm{~b}$ & $16.2 \mathrm{~b}$ & $12.3 \mathrm{a}(2.2)$ \\
\hline Sesleria caerulea & $10.0 \mathrm{~d}$ & $8.6 \mathrm{bc}$ & $8.0 \mathrm{~b}$ & $9.3 \mathrm{~cd}$ & 6.2 a (1.6) \\
\hline Sorghastrum nutans & $5.4 \mathrm{c}$ & $5.6 \mathrm{c}$ & $4.7 \mathrm{~b}$ & $5.2 \mathrm{ab}$ & $3.8 \mathrm{a}(1.4)$ \\
\hline \multicolumn{6}{|c|}{ Number of juvenile shoots } \\
\hline Briza media & $19.9 \mathrm{c}$ & $16.1 \mathrm{~b}$ & $16.5 \mathrm{~b}$ & $15.3 \mathrm{~b}$ & $10.2 \mathrm{a}(2.0)$ \\
\hline Deschampsia cespitosa & $5.8 \mathrm{~d}$ & $4.7 \mathrm{c}$ & $3.8 \mathrm{~b}$ & $4.5 \mathrm{c}$ & $2.0 \mathrm{a}(2.9)$ \\
\hline Koeleria glauca & $4.4 \mathrm{c}$ & $4.2 \mathrm{c}$ & $3.1 \mathrm{~b}$ & $3.4 \mathrm{~b}$ & $2.5 \mathrm{a}(1.8)$ \\
\hline Sesleria caerulea & $2.2 \mathrm{c}$ & $2.8 \mathrm{~d}$ & $1.9 \mathrm{~b}$ & $1.7 \mathrm{~b}$ & $1.1 \mathrm{a}(2.0)$ \\
\hline Sorghastrum nutans & $4.7 \mathrm{ab}$ & $5.3 \mathrm{~b}$ & $4.9 \mathrm{ab}$ & $4.8 \mathrm{ab}$ & $4.3 \mathrm{a}(1.1)$ \\
\hline \multicolumn{6}{|l|}{ Length of shoots $(\mathrm{cm})$} \\
\hline Briza media & $5.5 \mathrm{c}$ & $5.4 \mathrm{c}$ & $5.1 \mathrm{c}$ & $4.5 \mathrm{~b}$ & $3.6 \mathrm{a}(1.5)$ \\
\hline Deschampsia cespitosa & $3.2 \mathrm{~b}$ & $3.1 \mathrm{~b}$ & $3.1 \mathrm{~b}$ & $2.4 \mathrm{a}$ & $2.1 \mathrm{a}(1.5)$ \\
\hline Koeleria glauca & $4.0 \mathrm{c}$ & $3.9 \mathrm{c}$ & $3.7 \mathrm{c}$ & $3.1 \mathrm{~b}$ & $2.7 \mathrm{a}(1.5)$ \\
\hline Sesleria caerulea & $4.1 \mathrm{a}$ & $4.0 \mathrm{a}$ & $4.0 \mathrm{a}$ & $4.1 \mathrm{a}$ & $4.1 \mathrm{a}(1.0)$ \\
\hline Sorghastrum nutans & $15.9 \mathrm{~d}$ & $13.4 \mathrm{c}$ & $12.6 \mathrm{~b}$ & $13.6 \mathrm{c}$ & $11.3 \mathrm{a}(1.4)$ \\
\hline \multicolumn{6}{|l|}{ Length of leaves $(\mathrm{cm})$} \\
\hline Briza media & $30.3 \mathrm{~d}$ & $28.4 \mathrm{c}$ & $27.0 \mathrm{c}$ & $22.8 \mathrm{~b}$ & $15.1 \mathrm{a}(2.0)$ \\
\hline Deschampsia cespitosa & $24.2 \mathrm{c}$ & $24.1 \mathrm{c}$ & $23.3 \mathrm{c}$ & $20.7 \mathrm{~b}$ & 16.6 a (1.5) \\
\hline Koeleria glauca & $16.2 \mathrm{~d}$ & $14.9 \mathrm{c}$ & $13.2 \mathrm{~b}$ & $12.9 \mathrm{~b}$ & $10.7 \mathrm{a}(1.5)$ \\
\hline Sesleria caerulea & $24.5 \mathrm{~d}$ & $22.5 \mathrm{c}$ & $21.3 \mathrm{~b}$ & $20.5 \mathrm{~b}$ & $17.5 \mathrm{a}(1.4)$ \\
\hline Sorghastrum nutans & $34.5 \mathrm{ab}$ & $32.8 \mathrm{ab}$ & $32.8 \mathrm{ab}$ & $32.1 \mathrm{a}$ & $35.2 \mathrm{~b}(1.0)$ \\
\hline
\end{tabular}

*Average marked with the same letter within the species are not significantly different at the level of $\mathrm{p}=0.05$ 
Table 2. The effect of salinity stress on the number of dry leaves, percent of dry mass, young leaf greenness SPAD and tolerance indices of ornamental grasses

\begin{tabular}{|c|c|c|c|c|c|}
\hline \multirow{2}{*}{ Species } & \multicolumn{5}{|c|}{ Salt concentration $\left(\mathrm{g} \mathrm{NaCl} \cdot \mathrm{dm}^{-3}\right)$ (proportion to control in brackets) } \\
\hline & 0 & 5 & 10 & 15 & 30 \\
\hline \multicolumn{6}{|l|}{ Percentage of dry leaves } \\
\hline Briza media & $6.0 \mathrm{a}^{*}$ & $14.6 \mathrm{~b}$ & $18.3 \mathrm{~b}$ & $28.8 \mathrm{c}$ & $61.2 \mathrm{~d}(10.2)$ \\
\hline Deschampsia cespitosa & $9.4 \mathrm{a}$ & $12.7 \mathrm{a}$ & $17.2 \mathrm{~b}$ & $26.0 \mathrm{c}$ & $32.2 \mathrm{~d}(3.4)$ \\
\hline Koeleria glauca & $8.1 \mathrm{a}$ & $8.8 \mathrm{a}$ & $18.3 \mathrm{~b}$ & $29.8 \mathrm{c}$ & $38.6 \mathrm{~d}(4.8)$ \\
\hline Sesleria caerulea & $4.9 \mathrm{a}$ & $7.0 \mathrm{~b}$ & $10.5 \mathrm{c}$ & $12.5 \mathrm{~d}$ & $27.1 \mathrm{e}(5.5)$ \\
\hline Sorghastrum nutans & $12.3 \mathrm{a}$ & $21.7 \mathrm{~b}$ & $31.4 \mathrm{c}$ & $37.8 \mathrm{~d}$ & $45.0 \mathrm{e}(3.7)$ \\
\hline \multicolumn{6}{|l|}{ Percentage of dry mass } \\
\hline Briza media & $33.6 \mathrm{a}$ & $33.4 \mathrm{a}$ & $35.0 \mathrm{a}$ & $35.6 \mathrm{a}$ & $48.4 \mathrm{~b}(1.4)$ \\
\hline Deschampsia cespitosa & $33.5 \mathrm{a}$ & $32.2 \mathrm{a}$ & $37.6 \mathrm{ab}$ & $40.9 \mathrm{~b}$ & $46.0 \mathrm{c}(1.4)$ \\
\hline Koeleria glauca & $37.2 \mathrm{a}$ & $46.5 \mathrm{a}$ & $49.2 \mathrm{a}$ & $67.5 \mathrm{~b}$ & $82.4 \mathrm{c}(2.2)$ \\
\hline Sesleria caerulea & $55.8 \mathrm{a}$ & $51.0 \mathrm{a}$ & $56.4 \mathrm{a}$ & $60.8 \mathrm{a}$ & $59.8 \mathrm{a}(1.1)$ \\
\hline Sorghastrum nutans & $43.0 \mathrm{a}$ & $44.2 \mathrm{a}$ & $47.0 \mathrm{a}$ & $39.0 \mathrm{a}$ & $39.0 \mathrm{a}(0.9)$ \\
\hline \multicolumn{6}{|c|}{ Young leaf greenness SPAD } \\
\hline Briza media & $35.4 \mathrm{a}$ & $37.1 \mathrm{a}$ & $42.2 \mathrm{~b}$ & $43.5 \mathrm{~b}$ & $43.6 \mathrm{~b}(1.2)$ \\
\hline Deschampsia cespitosa & $31.4 \mathrm{a}$ & $32.5 \mathrm{a}$ & $35.2 \mathrm{~b}$ & $35.3 \mathrm{~b}$ & $36.4 \mathrm{~b}(1.2)$ \\
\hline Koeleria glauca & - & - & - & - & - \\
\hline Sesleria caerulea & $44.4 \mathrm{~b}$ & $44.7 \mathrm{~b}$ & $44.2 \mathrm{~b}$ & $44.4 \mathrm{~b}$ & $41.1 \mathrm{a}(0.9)$ \\
\hline Sorghastrum nutans & $26.5 \mathrm{a}$ & $25.2 \mathrm{a}$ & $24.5 \mathrm{a}$ & $24.9 \mathrm{a}$ & $26.1 \mathrm{a}(1.0)$ \\
\hline \multicolumn{6}{|l|}{ Tolerance index (\%) } \\
\hline Briza media & $100.0 \mathrm{~d}$ & $78.2 \mathrm{c}$ & $72.1 \mathrm{c}$ & $61.1 \mathrm{~b}$ & $45.7 \mathrm{a}(2.2)$ \\
\hline Deschampsia cespitosa & $100.0 \mathrm{c}$ & $69.4 \mathrm{~b}$ & $62.6 \mathrm{~b}$ & $51.5 \mathrm{a}$ & $42.8 \mathrm{a}(2.3)$ \\
\hline Koeleria glauca & $100.0 \mathrm{~d}$ & $86.5 \mathrm{c}$ & $76.9 \mathrm{~b}$ & $72.1 \mathrm{ab}$ & $65.1 \mathrm{a}(1.5)$ \\
\hline Sesleria caerulea & $100.0 \mathrm{c}$ & $72.9 \mathrm{~b}$ & $72.8 \mathrm{~b}$ & $74.9 \mathrm{~b}$ & $57.3 \mathrm{a}(1.7)$ \\
\hline Sorghastrum nutans & $100.0 \mathrm{e}$ & $87.6 \mathrm{~d}$ & $70.6 \mathrm{c}$ & $60.1 \mathrm{bc}$ & $49.2 \mathrm{a}(2.0)$ \\
\hline
\end{tabular}

* Explanation as in Table 1

Salinity results in plant dehydration, which may also be analyzed based on the percentage content of dry mass. In this experiment, an increase in dry matter was only significant at $15 \mathrm{~g} \mathrm{NaCl} \cdot \mathrm{dm}^{-3}$ in D. cespitosa and $K$. glauca (Table 2). Dry mass of S. caerulea and $S$. nutans was not different compairing with control even at $30 \mathrm{~g} \mathrm{NaCl} \cdot \mathrm{dm}^{-3}$. The contents of dry mass were higher 2.2 times in $K$. glauca and 1.4 times in B. media, and D. cespitosa. Glenn (1987) showed that all the 18 investigated grass species responded to salinity $\left(60-540 \mathrm{~mol} \cdot \mathrm{m}^{-3} \mathrm{NaCl}\right)$ by losing water. Also, Farooq and Azam (2006) showed a lower water content in wheat leaves under the influence of salinity $(100-250 \mathrm{mM} \mathrm{NaCl})$. A lack of an influence of salinity on changes in dry mass in halophytes was shown by Longstreth and Strain (1977) in Spartina alterniflora and by Wu et al. (1998) in Spartina patens. This suggests resistance of these species to substrate salinity due to only a moderate water loss. Moreover, a high percentage content of dry matter in plants not irrigated with saline in both these species is typical of halophytes, which was also shown by Glenn (1987). According to that author, halophytic grasses contain less water than glycophytic grasses grown with no salinity.

A higher value of the chlorophyll index in this study, was recorded in young leaves of B. media and D. cespitosa under the influence of substrate salinity of 15 and $30 \mathrm{~g} \mathrm{NaCl} \cdot \mathrm{dm}^{-3}$ (Table 2). Withering of old leaves and probably root system damage could have also influence on an enhancement of photosynthesis and accumulation of its products in young leaves. Comparable values of the chlorophyll index in leaves of $S$. caerulea and $S$. nutans, irrespective of salinity levels, indicate lesser disturbances in the course of basic physiological reactions. Generally, 
salinity causes necroses, yellowing and a decrease of chlorophyll content in mature leaves. A reduction of chlorophyll content in leaves of Hyacinthus orientalis, under the influence of salinity, was reported by Türkoglu et al. (2011), Longstreth and Strain (1977) in Spartina alterniflora, as well as Nabati et al. (2013) in Sorghum bicolor. The negative effects of salinity connected with a reduction of the length of leaves and the withering of mature leaves may cause a greater efficiency of photosynthesis in young leaves. A decreased content of $\mathrm{Na}^{+}$ions in young leaves due to a low transpiration rate, caused a short life of those leaves and defense mechanisms. This contributes to a lesser damage of photosynthesis (Singla-Pareek et al. 2003).

The tolerance index may reliably illustrate the effect of substrate salinity on plants. In this experiment, it was shown that with an increase in salinity, its values decreased in all the tested grasses, even in the species that showed resistance reactions (Table 2). In this study, B. media, D. cespitosa and S. nutans had lower values of the tolerance index than $K$. glauca and $S$. caerulea. K. glauca under the influence of salinity caused by the greatest salt doses ( 15 and $30 \mathrm{~g} \mathrm{NaCl} \cdot \mathrm{dm}^{-3}$ ) exhibited a high percentage content of dry mass, which in this analysis focused on the tolerance index based on plant dry mass and is confirmed by high values of this index. B. media, D. cespitosa, and $S$. nutans naturally grow on soils poor in nutrients. For this reason, they are not adapted to large concentrations of salt in soil solution. K. glauca are found in dry places and sandy soils (Krechowski et al. 2012). Probably due to drought resistance, it has large values of content of dry matter. S. caerulea grows on wet meadows and low peat bogs. According to Misra (2003), plants which prefer moist soils, are generally fast-growing, have a high nutrient uptake and can withstand fluctuations of wet/dry periods. They are able to utilize increased solubility of nutrients more.

\section{CONCLUSIONS}

1. Briza media, had the strongest negative response to all $\mathrm{NaCl}$ concentrations, even at 5 and $10 \mathrm{~g} \cdot \mathrm{dm}^{-3}$, manifested in the number of shoots, length of leaves, percentage of dry leaves and tolerance index.
2. Tolerance index was decreased in all genotypes already at 5 and $10 \mathrm{~g} \mathrm{NaCl} \cdot \mathrm{dm}^{-3}$, the most in D. cespitosa and S. caerulea. At $30 \mathrm{~g} \mathrm{NaCl} \cdot \mathrm{dm}^{-3}$, the lowest tolerance index had D. cespitosa and B. media.

3. Dry mass and leaf greenness were under the least influence of salinity stress.

\section{Acknowledgment}

Work was financially supported by Ministry of Science and Higher Education as part of the research to sustain the research potential of the Department of Ornamental Plants at the University of Life Sciences in Poznan.

\section{REFERENCES}

Cheong M.S., Yun D.-J. 2007. Salt-stress signaling. Journal of Plant Biology 50(2): 148-155. DOI: 10.1007/bf03030623.

Cunningham M.A., Snyder E., Yonkin D., Ross M., Elsen T. 2008. Accumulation of deicing salts in soils in an urban environment. Urban Ecosystems 11: 17-31. DOI: 10.1007/s11252-007-0031-x.

Dana M.N. 2002. Ornamental grasses and sedges as new crops. In: Janick J., Whipkey A. (Eds.), Trends in new crops and new uses, ASHS Press, Alexandria, VA., pp. 473-476.

Farooq S., Azam F. 2006. The use of cell membrane stability (CMS) technique to screen for salt tolerant wheat varieties. Journal of Plant Physiology 163: 629-637. DOI: 10.1016/j.jplph.2005.06.006.

Foerster K. 1978. Einzug der Gräser und Farne in die Gärten. Neumann Verlag Leipzig, Radebeul, 255 p. [in German]

Glenn E.P. 1987. Relationship between cation accumulation and water content of salt-tolerant grasses and a sedge. Plant Cell and Environment 10: 205-212. DOI: 10.1111/1365-3040.ep11602236.

Gregorczyk A., Raczyńska A. 1997. Study of the correlation between Arnon's method and measurements of chlorophyll meter. Zeszyty Naukowe Akademii Rolniczej w Szczecinie 181: 119-123. [in Polish with English abstract]

Gregorczyk A., Raczyńska A., Pacewicz K. 1998. Analysis of standardization curves of chlorophyll content for the basic grain species. Biuletyn Magnezologiczny 3(1): 19-21. [in Polish with English abstract]

Henschke M. 2014. Ornamental grasses - a new group of plants for urban greenery. In: Kosmala M. (Ed.), 
Kierunki zmian terenów zieleni w miastach, Toruń, Poland, pp. 377-398. [in Polish with English abstract]

Howard K.W.F., Maier H. 2007. Road de-icing salt as a potential constraint on urban growth in the Greater Toronto Area, Canada. Journal of Contaminant Hydrology 91: 146-170. DOI: 10.1016/j.jconhyd.2006.10.005.

Javid M.G., Sorooshzadeh A., Moradi F., Sanavy S.A.M.M., Allahdadi I. 2001. The role of phytohormones in alleviating salt stress in crop plants. Australian Journal of Crop Science 5(6): 726-734.

Katerji N., van Hoorn J.W., Hamdy A., Mastrorilli M. 1998. Response of tomatoes, a crop of indeterminate growth, to soil salinity. Agricultural Water Management 38(1): 59-68. DOI: 10.1016/s03783774(98)00051-1.

Krechowski J., Bzdon G., Sikorski R. 2012. Dry grassland and thermophilous forest margin species in the flora of gravel pits of the Wysoczyzna Siedlecka plateau. Annales Universitatis Mariae CurieSkłodowska, Biologia 67(1): 43-56. DOI: 10.2478/v10067-012-0012-1.

Longstreth D.J., Strain B.R. 1977. Effects of salinity and illumination on photosynthesis and water balance of Spartina alterniflora Loisel. Oecologia (Berl.) 31: 191-199. DOI: 10.1007/bf00346920.

Misra A. 2003. Influence of water conditions on growth and mineral nutrient uptake of native plants on clacareous soil. Thesis, Department of Ecology, Plant Ecology and Systematics, Lund University, Sweden. http://lup.lub.lu.se/search/record/466038

Munns R. 2002. Comparative physiology of salt and water stress. Plant Cell and Environment 25: 239-250. DOI: 10.1046/j.0016-8025.2001.00808.x.

Nabati J., Kafi M., Masoumi A., Mehrjerdi M.Z. 2013. Effect of salinity and silicon application on photosynthetic characteristics of sorghum (Sorghum bicolor L.). International Journal of Agricultural Sciences 3(4): 483-492.

Singla-Pareek S.L., Reddy M.K., Sopory S.K. 2003. Genetic engineering of the glyoxalase pathway in tobacco leads to enhanced salinity tolerance. Proceedings of the National Academy of Sciences 100(25): 14672-14677. DOI: 10.1073/pnas.2034667100.
Rani R.J. 2011. Salt stress tolerance and stress protein in pearl millet (Pennisetum glaucum (L.) R. Br.). Journal of Applied Pharmaceutical Science 1(7): 185-188.

Shetty K.G., Hetrick B.A.D., Schwab A.P. 1995. Effects of mycorrhizae and fertilizer amendments on zinc tolerance of plants. Environmental Pollution 88(3): 308-314. DOI: 10.1016/0269-7491(95)93444-5.

Siyal A.A., Siyal A.G., Abro Z.A. 2002. Salt affected soils their identification and reclamation. Pakistan Journal of Applied Sciences 2: 537-540. DOI: 10.3923/jas.2002.537.540.

Sudhakar Ch., Lakshmi A., Giridarakumar S. 2001. Changes in the antioxidant enzyme efficacy in two high yielding genotypes of mulberry (Morus alba L.) under $\mathrm{NaCl}$ salinity. Plant Science 161: 613619. DOI: 10.1016/s0168-9452(01)00450-2.

Türkoglu N., Erez M.E., Battal P. 2011. Determination of physiological responses on hyacinth (Hyacinthus orientalis) plant exposed to different salt concentrations. African Journal of Biotechnology 10(32): 6045-6051.

Vasquez E.A., Glenn E.P., Guntenspergen G.R., Brown J.J., Nelson S.G. 2006. Salt tolerance and osmotic adjustment of Spartina alterniflora (Poaceae) and the invasive M haplotype of Phragmites australis (Poaceae) along a salinity gradient. American Journal of Botany 93(12): 1784-1790. DOI: 10.3732/ajb.93.12.1784.

Warren R.S., Baird L.M., Thompson A.K. 1985. Salt tolerance in cultured cells of Spartina pectinata. Plant Cell Reports 4: 84-87. DOI: 10.1007/bf00269213.

Warren R.S., Brockelman P.M. 1989. Photosynthesis, respiration, and salt gland activity of Distichlis spicata in relations to soil salinity. Botanical Gazette 150(4): 346-350. DOI: 10.1086/337780.

Wu J., Seliskar D.M., Gallagher J.L. 1998. Stress tolerance in the marsh plant Spartina patens: Impact of $\mathrm{NaCl}$ on growth and root plasma membrane lipid composition. Physiologia Plantarum 102: 307-317. DOI: 10.1034/j.1399-3054.1998.1020219.x.

Xiong L., Zhu J.-K. 2002. Salt tolerance. In: Somerville C.R., Meyerowitz E.M. (Eds.), The Arabidopsis book. Society of Plant Biologists, Rockville, MD. DOI: 10.1199/tab.0048. 